\title{
Lymphoblast Count
}

National Cancer Institute

\section{Source}

National Cancer Institute. Lymphoblast Count. NCI Thesaurus. Code C102278.

The determination of the amount of lymphoblasts (immature cells that differentiate to form lymphocytes) present in a sample. 